
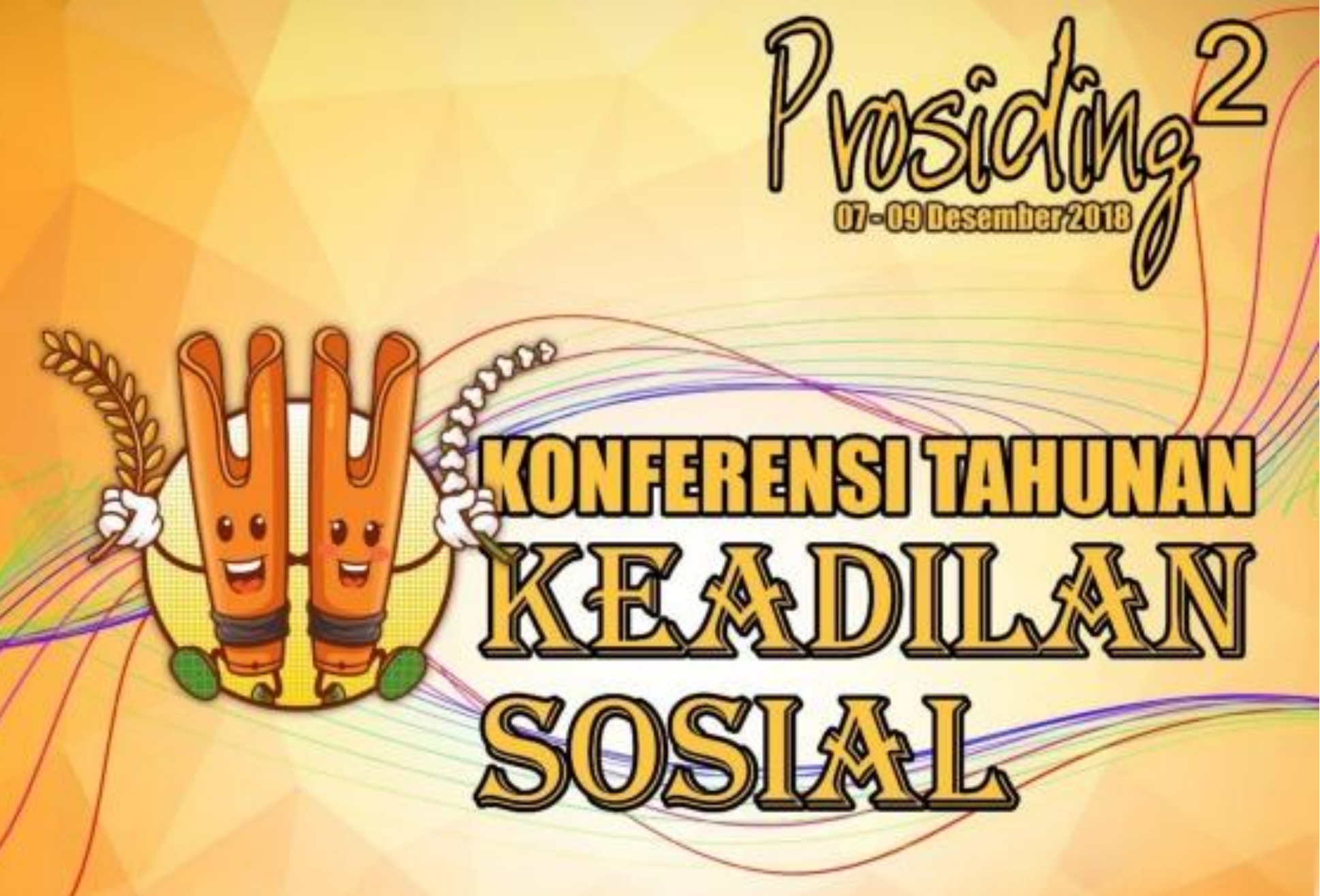

Kesehatan, Pangan, Bencana, Lingkungan dan Keadilan Sosial

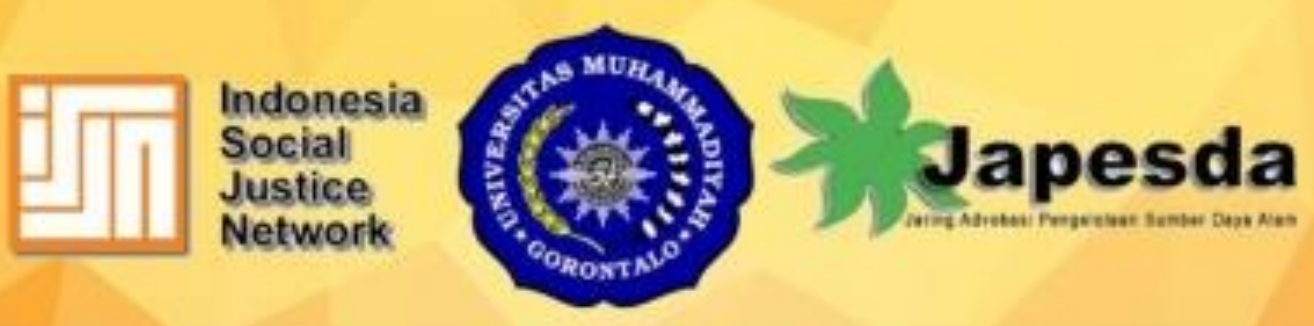




\section{Prosiding Konferensi Tahunan Keadilan Sosial}

Kesehatan, Pangan, Bencana, Lingkungan dan Keadilan Sosial

Copyright (c) 2019

Pusat Analisis Regional Indonesia

All rights reserved

Diterbitkan Pertama kali oleh Pusat Analisis Regional (Pusar) Indonesia Jl. Cipinang Muara Raya No. 18, Jakarta Timur - 13420

JL. D.J. Rahman RW-03/RT-08 Hepuhulawa, Limboto, Gorontalo 96212

PUSAR - 230119

Editor: Basri

Amin Rahman

Dako

Muhammad Sarlin

Muhammad Yasser Arafat

ISBN: 978-602-53535-2-9

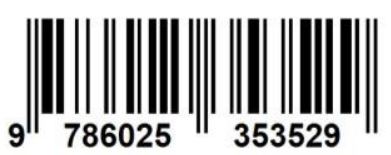

Hak Cipta Dilindungi Undang-Undang

Dilarang mengutip atau memperbanyak seluruh atau sebagian isi buku ini tanpa izin tertulis dari penulis dan penerbit
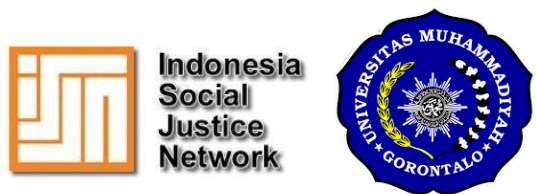

Japesda 


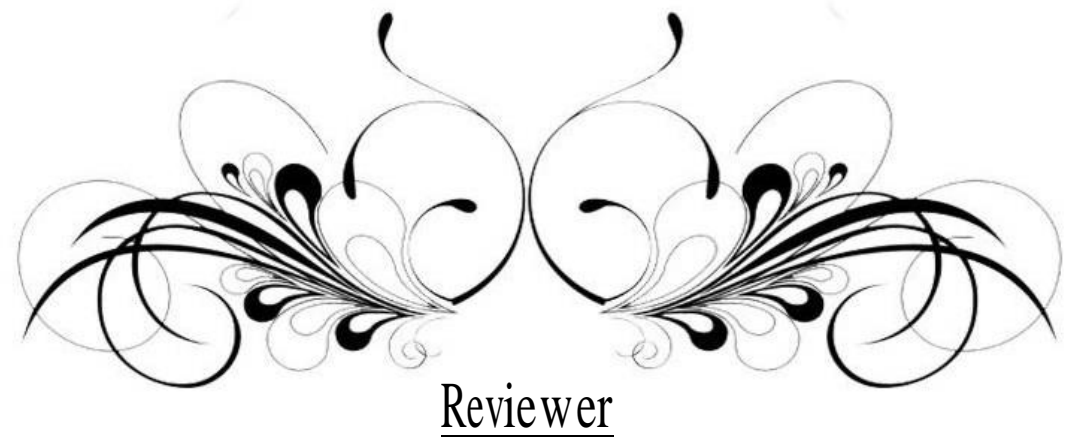

Dr. Hj. Yuszda K Salimi.,M.Si (UMGO)

Dr. Ir. Hasim.,M.Si (UNG)

Muh.Firyal Akbar.,S.IP.,M.Si (UMGO)

Nurain Lapolo, MSi (Japesda)

Helman Manay (UNG)

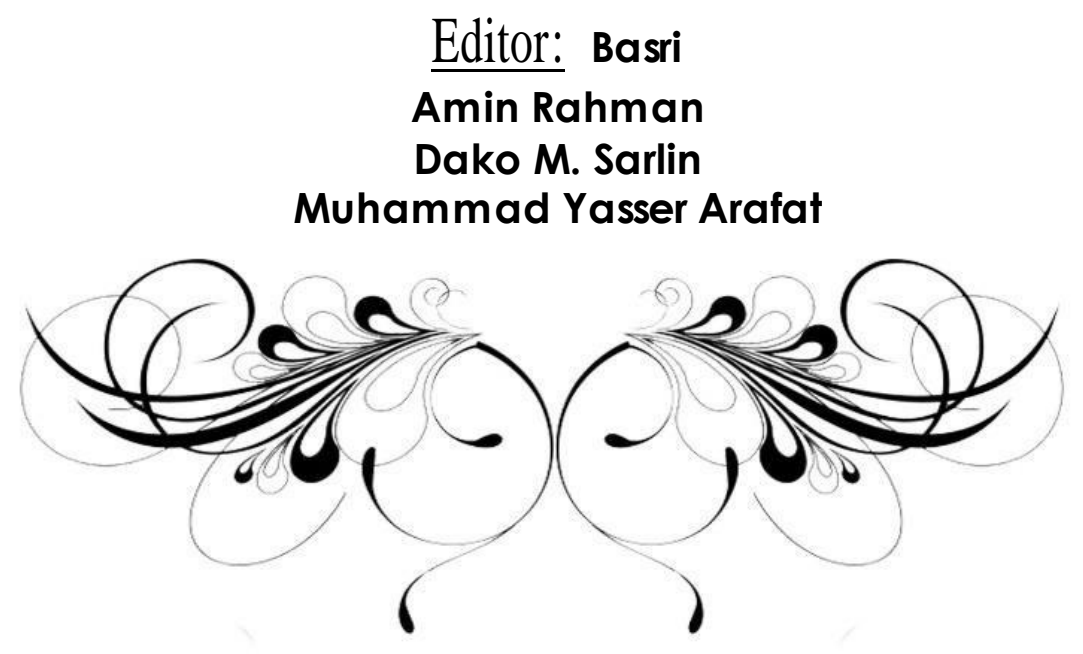




\section{Kata Pengantar}

Segala puji dan syukur bagi Tuhan Yang Maha Esa yang telah memberikan kemudahan sehingga buku prosiding Konferensi Tahunan Keadilan Sosial yang mengusung tema: "Menggugah Kepedulian Cendekiawan Muda Terhadap Isu-isu Keadilan Sosial dan Menyatukan Langkah untuk Indonesia yang Lebih Baik" bisa disajikan kepada masyarakat luas.

Buku prosiding ini memuat sejumlah artikel ilmiah hasil penelitian dan praktik terbaik upaya mewujudkan keadilan sosial di Indonesia yang telah dipresentasikan pada tanggal 08 Desember 2018 di Universitas Muhammadiyah Gorontalo. Tulisan ilmiah dalam prosiding ini dibagi dalam empat kelompok sesuai sub-tema konferensi yaitu: 1. Pendidikan, 2. Kesehatan, 3. Bencana, Lingkungan Hidup dan Ketahanan Pangan dan 4. Politik, Humanitas dan Industri 4.0. Konferensi ini terlaksana berkat kerja sama Indonesia Social Justice Network (ISJN) dan Jaringan Pengelola Sumber Daya Alam (Japesda) serta Universitas Muhammadiyah Gorontalo atas dukungan pembiayaan dari the Ford Foundation

Konferensi Keadilan Sosial merupakan program rutin tahunan ISJN yang dimaksudkan sebagai medium bagi para akademisi, ilmuwan, peneliti, aktivis, jurnalis dan berbagai pemangku kepentingan untuk berbagi pengetahuan ilmiah dan praktik terbaik dalam memperjuangkan keadilan sosial di Indonesia. ISJN merupakan perkumpulan 361 akademisi, praktisi dan pegiat keadilan social di Indonesia, alumni penerima beasiswa International Fellowship Program (IFP) yang telah menempuh pendidikan tinggi diberbagai perguruan tinggi terkemuka di dunia atas dukungan pembiayaan penuh dari The Ford foundation. ISJN berkomitmen penuh untuk mewujudkan Keadilan Sosial di Indonesia dan selalu mengajak seluruh elemen masyarakat untuk bersama-sama mengupayakan agar visi ini menjadi sebuah kenyataan.

Pada tahun 2018, konferensi ini secara khusus memadukan peneliti dan aktivis muda dengan senior sebagai upaya untuk membangun kesadaran generasi muda terhadap berbagai permasalahan sejak dini dan merangsang tumbuhnya regenerasi perjuangan keadilan sosial di Indonesia. Ajang ilmiah ini menjadi wadah berbagi pengalaman lintas usia, disiplin dan geografis. Hal ini senada dengan filosofi polo palo, instrumen musik tradisional Gorontalo yang terbuat dari bambu dan mengeluarkan nada indah untuk memanggil, mengingatkan dan mengumpulkan warga untuk melakukan kegiatan bersama. Polo palo dipilih sebagai ikon konferensi untuk merepresentasikan semangat kolaborasi seluruh elemen bangsa dalam mewujudkan keadilan sosial . Kesuksesan panitia dalam memfasilitasi kolaborasi berbagi ilmu dan pengalaman dapat dilihat dari keberagaman peserta konferensi ini. Mulai dari peneliti muda berusia 14 tahun dari pedalaman Provinsi Sumatera Selatan sampai Profesor dari salah satu universitas di Provinsi Sulawesi Utara.

ISJN menyampaikan terima kasih yang mendalam kepada berbagai pihak yang telah mendukung penyelenggaraan kegiatan ini sehingga dapat terlaksana dengan baik dan sukses. Kami menghaturkan penghargaan setinggi-tingginya kepada Japesda, pimpinan dan civitas akademika Universitas Muhammadiyah Gorontalo, Pemerintah Kota Gorontalo, para pembicara kunci dan seluruh pemakalah serta para peserta konferensi. Salam hormat kami juga kepada warga Gorontalo dan semua pihak yang tidak bisa kami sebutkan secara mendetail atas sambutan, keramahtamahan dan suguhan beragam seni budaya serta kuliner yang mencerminkan kekayaan bumi nusantara.

Gorontalo, Februari 2019

Martadinata Basyir, DVM., MPH. National Presidium The Indonesian Social Justice Network 


\section{Daftar Isi}

\section{Bab Pangan \& Lingkungan Hidup}

MEMAKNAI LOGIKA MENAJEMEN BENCANA INDONESIA DALAM STUDI KASUS BENCANA (LOMBOK: Sebuah Tinjauan Kritis)

Laode Muhamad Fathun (Halaman 1 s/d 11)

INDIKASI GAS DANGKAL RAMAH LINGKUNGAN MENJADI CADANGAN ENERGI BAGI MASYARAKAT PESISIR DANAU LIMBOTO GORONTALO Delyuzar Ilahude (Halaman 12 s/d 19)

INTEGRASI TERNAK SAPI POTONG - JAGUNG BERWAWASAN LINGKUNGAN Femi Hadidjah Elly ${ }^{1}$, Agustinus Lomboan ${ }^{1}$, Charles L. Kaunang ${ }^{1}$, Derek Polakitan ${ }^{2}$ dan Syarifuddin ${ }^{3}$ (Halaman 20 s/d 28)

KONSUMSI PANGAN PRODUK PETERNAKAN RUMAHTANGGA PESISIR PANTAI

Sintya J.K. Umboh ${ }^{1}$, Femi Hadidjah Elly ${ }^{l}$, Jolanda K.J, Kalangi ${ }^{1}$, Tilly F.D. Lumy ${ }^{l}$, dan Derek Polakitan ${ }^{2}$ (Halaman 29 s/d 36)

PEMANFAATAN LARUTAN MENIRAN (PHYLLANTHUS NIRURI) PADA LAMA PERENDAMAN YANG BERBEDA TERHADAP DAYA TELUR SERTA KELANGSUNGAN HIDUP LARVA UMUR 14 HARI PADA IKAN MAS KOI (CYPRINUS CARPIO)

Rasmin Mortiga ${ }^{1}$, Hasim $^{2}$, Syamsuddin ${ }^{2}$ (Halaman 37 s/d 46)

MODEL KONSEPTUAL IMPLEMENTASI KEBIJAKAN PENGEMBANGAN WISATA ALAM DI TAMAN NASIONAL BOGANI NANI WARTABONE (TNBNW) PROVINSI GORONTALO

Irwan Bempah (Halaman 47 s/d 58)

FASILITASI PENGELOLAAN WILAYAH PERLINDUNGAN LAUT BERBASIS MASYARAKAT DESA LAMBANGAN, KECAMATAN PAGIMANA, KABUPATEN BANGGAI

Rivon Paino (Halaman 59 s/d 69)

ANALISIS PEMANGKU KEPENTINGAN DALAM PENGELOLAAN EKOSISTEM MANGROVE DI DESA MOOTINELO KABUPATEN GORONTALO UTARA Mohamad Sayuti Djau ${ }^{1}$, Supandri Badu ${ }^{2}$ (Halaman 70 s/d 79)

TATA KELOLA "SUBAK" PADA MASYARAKAT SUKU BALI TRANSMIGRASI Dewa Oka Suparwata dan Taufik Jarot Andrayanto (Halaman 80 s/d 93)

KARAKTERISTIK FUNGSI LAHAN DI KECAMATAN DUNGINGI KOTA GORONTALO

Mohammad Imran ${ }^{1}$, Novita Shamin ${ }^{2}$ dan Imam Mashudi (Halaman 94 s/d 108)

KAJIAN POLA KONSUMSI PANGAN MASYARAKAT PEDESAAN

Siskawati J. Biki ${ }^{1}$, Dewa Oka Suparwata ${ }^{2}$ dan Denny Latama ${ }^{3}$ (Halaman 109 s/d 117)

KARAKTERISTIK SOSIAL EKONOMI MASYARAKAT SUB DAS ALO TERHADAP PERILAKU PEMANFAATAN FISIK LAHAN

Risman Jaya ${ }^{1}$, Ahmad Syamsu Rijal $S^{2}$ (Halaman 118 s/d 127) 


\title{
TATA KELOLA "SUBAK" PADA MASYARAKAT SUKU BALI TRANSMIGRASI
}

\author{
Dewa Oka Suparwata dan Taufik Jarot Andrayanto \\ Program Studi Agribisnis, Fakultas Ilmu-Ilmu Pertanian, Universitas Muhammadiyah Giorontalo.

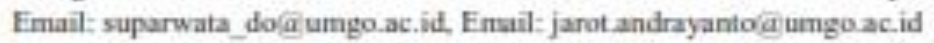

\begin{abstract}
ABSTRAK
Subak ialah model pengelolaan irigasi yang memiliki karakteristik sosio-agraris-religius, dengan konsep "Tri Hita Karana" pada masyarakat suku Bali. Fokus kajian ialah mengkaji tata kelola subak pada masyarakat suku Bali transmigrasi, guna mendukung keberlanjutan penyediaan air irigasi. Penelitian ini dilaksanakan pada Bulan Juni sampai Oktober 2017, di Desa Duata Karya, Kecamatan Masama Kabupaten Banggai, Provinsi Sulawesi Tengah. Desain penelitian survei, sampel ditentukan dengan metode snowball sampling. Teknik analisis data deskriptif kualitatif, dengan tahapan meliputi: indexing, interpretasi, connecting, simpulan dan penyajian data. Hasil penelitian menunjukkan bahwa: (1) Pengelolaan organisasi kesubakan di Desa Duata Karya yakni pekaseh, wakil pekaseh, ketua kelompok tani dan anggota kelompok, yang memiliki tupoksinya masing-masing, dan (2) Pengelolaan subak dikelompokkan menjadi pengelolaan fisik, meliputi pengelolaan sumberdaya air, pengelolaan bangunan irigasi (empelan, aungan, pintu air pembagi, telabah gede, telabah cenik), juga pengelolaan terhadap bangunan pura ulun suwi dan pura bedugul. Sedangkan pengelolaan non fisik meliputi organisasi dan kelembagaan, serta pengelolaan regulasi/awig-awig kesubakan. Hal ini secara empiris sistem subak berimplikasi pada pemerataan pembagian air irigasi ke lahan sawah petani.
\end{abstract}

Kata Kunci: Irigasi, Subak, Masyarakat Suku Bali, Transmigrasi 


\section{PENDAHULUAN}

Indonesia merupakan suatu negara yang memiliki agama, suku, adat istiadat/tradisi, serta ras yang beranekaragam. Perbedaan tersebut melahirkan suatu keunikan diantara masyarakat penganutnya yang tersebar di wilayah/daerah satu dengan lainnya. Demikian juga halnya dengan tradisi bertani yang dianutnya yang telah diwariskan secara turun temurun oleh nenek moyang mereka. Antara daerah satu dengan yang lainnya memiliki perbedaan dari sikap dan perilaku bertani masyarakat. Sebut saja suku Bali, yang dalam kehidupan mereka banyak diwariskan oleh budaya/tradisi dalam melakukan bercocok tanam di lahan, baik di lahan kering maupun lahan basah/sawah.

Suku Bali khususnya adalah suku yang secara dominan terdapat dan mendiami pulau Bali. Bali merupakan suatu daerah yang sangat unik, elegan, lestari, multicultural, sehingga memiliki nilai tambah yang menjadi daya tarik wisatawan datang ke pulau Bali. Disamping daerah yang demikian mempesona, baik dari lautan, daratan, serta kondisi udara yang sejuk, Bali di kenal dengan sebutan "Pulau Seribu Pura". Sebab disetiap rumah masyarakat suku Bali terdapat "Merajan/sanggah" sebagai tempat untuk memuja Ida Sang Hyang Widhi Wase (Tuhan Yang Maha Esa). Berkaitan dengan itu, masyarakat Bali mengenal suatu konsep kehidupan terdiri dari "Parahyangan, Pawongan, dan Palemahan". Demikian uniknya masyarakat suku Bali dalam menjalani kehidupan mereka. Demikian juga halnya dengan kebiasaan bertani masyarakat Bali sangat kental dengan tradisi yang mereka yakini yang telah diwariskan pendahulunya. Salah satu tradisi bertani yang dianut sampai saat ini adalah tradisi "Subak".

Menurut Peraturan Daerah Provinsi Bali No. 02/PD/DPRD/1972 dinyatakan bahwa subak adalah suatu masyarakat hukum adat yang memiliki karakteristik sosioagraris-religius, yang merupakan perkumpulan petani yang mengelola air irigasi di lahan sawah. Pengaturan air irigasi ini tidak jauh berbeda dengan pengaturan irigasi pada umumnya. Namun, pada masyarakat suku Bali sistem irigasi ini menjadi sangat menarik. Konsep yang dibangun dengan sistem subak ini adalah menganut konsep "Tri Hita Karana". Konsep Tri Hita Karana yang berartikan tiga hubungan yang sangat harmonis. Konsep tersebut menggambarkan bahwa: hubungan yang harmonis antara manusia dengan Tuhan yang Maha Esa, (2) Hubungan harmonis antara manusia dengan sesama manusia, dan (3) hubungan yang harmonis antara manusia dengan alam semesta/lingkungan. Dengan dasar itu, sehingga disetiap lahan persawahan suku Bali/kelompok tani Bali terdapat satu pura suci sebagai tempat pemujaan dan melakukan persembahan. Tujuan dari persembahan tersebut adalah ucapan rasa terima kasih kita kepada Tuhan karena telah memberikan limpahan rejeki melalui hasil tanaman pertanian. Di pulau Bali pura yang terdapat di tengah-tengah persawahan dikenal dengan nama "Pura Bedugul". Pada masyarakat Bali transmigrasi mengenal dengan sebutan "Pura Beji" atau "Pura Ulunsui". Tetapi, dalam konteks pemujaannya adalah sama. Sedangkan mekanisme pengaturan jaringan irigasi subak ditentukan masing-masing oleh "bendesa adat/kerame adat".

Beberapa peneliti mengatakan keberadaan subak di Bali sangat beragam dalam manajerial suplai air ke lahan persawahannya. Menurut Sutawan (2001), bahwa eksistensi subak sangat bervariasi menurut keragaman aktivitas operasi dan pemeliharaan serta tingkatan organisasinya. Di beberapa satuan wilayah sungai (SWS) di Bali, variasi sistem subak menurut tingkatannya terdiri atas tempek (sub-subak), subak, subak gede, dan subak agung. Subak gede merupakan penggabungan beberapa subak yang masing-masing memperoleh air dari bangunan pengambilan yang sama (bendung/empelan) ke dalam suatu wadah koordinasi tanpa menghilangkan kemandirian dari masing-masing subak yang tergabung tersebut terutama dalam hal mengatur urusan rumah tangga sendiri, meskipun untuk urusan ke luar masih perlu melalui atau atas sepengetahuan pimpinan wadah koordinasi yang bersangkutan. 
Suyastiri (2012), menjelaskan bahwa Subak sebagai suatu organisasi petani pemakai air yang bersifat sosio-agrarisreligius atau pemerintahan air yang merupakan sekumpulan sawah-sawah, dicirikan oleh: (1) mendapat air dari sumber yang sama, (2) merupakan suatu badan yang mempunyai hak otonomi penuh baik ke dalam maupun ke luar. Otonomi ke dalam yaitu dalam hal mengatur/mengurus kepentingan rumahtangganya sendiri seperti; membentuk pengurus, mengatur keuangan, membuat peraturan baik tertulis maupun tidak tertulis yang tercermin dari adanya awig-awig subak, menjaga ketertiban dan kesejahteraan anggotanya. Otonomi ke luar dalam artian bebas mengadakan hubungan langsung dengan pihak luar secara mandiri. (3) adanya salah satu atau lebih "bedugul" yaitu bangunan suci tempat pemujaan Tuhan dalam manifestasinya sebagai "Dewi Sri".

Tradisi subak yang sekian lama dianut oleh petani Bali sampai sekarang masih dipegang erat oleh masyarakat Bali. Namun, perkembangan zaman telah merubah sedikit demi sedikit pola masyarakat tersebut. Suatu contoh adalah "pengempon" dari pura subak yang semakin berkurang akibat alih fungsi lahan sawah yang berada di dataran tinggi menjadi bangunan villa. Seperti halnya dijelaskan oleh Sari (2013), bahwa pada tahun 2008 tercatat luas subak Gebang Gading Atas adalah 135 hektar dan sampai pada tahun 2012 tercatat masih 120 hektar. Alih fungsi lahan sawah pada subak menyebabkan pengurangan pengempon pura bedugul dari 174 menjadi 163 pengempon. Tetapi, subak di Bali masih terjaga dan dilakukan sampai saat ini.

Begitu apiknya pengaturan air irigasi yang terdapat di Bali, sehingga daerah-daerah dengan tofografi bergunung hingga bukit dan kemiringan lereng curam pun masih mendapatkan suplay air untuk menunjang pertumbuhan tanaman padi. Sejalan dengan pertambahan Provinsi di Indonesia dan perkembangan zaman, masyarakat suku Bali banyak yang melakukan transmigrasi ke daerah-daerah di luar Bali. Transmigrasi ini dilakukan baik oleh program yang dilakukan pemerintah atau atas kemauan dirinya sendiri.
Salah satunya adalah wilayah di Kabupaten Banggai, Provinsi Sulawesi Tengah.

Kabupaten Banggai merupakan daerah yang terletak antara $122^{\circ} 23^{\prime}-124^{\circ} 20^{\prime}$ Bujur Timur dan $0^{\circ} 30^{\circ}-2^{\circ} 20^{\circ}$ Lintang selatan. Luas Wilayah Kabupaten Banggai mencapai $9.672,70 \mathrm{Km}^{2}$, secara administrasi tahun 2010 dibagi dalam 18 kecamatan dengan 46 kelurahan, 291 desa dan 2 Unit Pemukiman Transmigrasi (UPT). Rata-rata curah hujan selama tahun 2010 berkisar antara $3,4 \mathrm{~mm}$ sampai $284,9 \mathrm{~mm}$, dengan suhu udara ratarata berkisar antara $26,8^{\circ} \mathrm{C}$ sampai $29,4^{\circ} \mathrm{C}$ (BPS Kabupaten Banggai, 2011). Jumlah penduduk Kabupaten Banggai mencapai 334.561 jiwa, dengan sebaran masyarakat suku Bali transmigrasi mencapai 19.567 jiwa. Daerah irigasi Kabupaten Banggai dibagi kedalam dua bagian yakni irigasi potensial mencapai $30.723,85$ dan fungsional mencapai $18.184,28$, yang diperuntukkan untuk pengairan lahan sawah seluas $14.924,66$ ha (BPS Kabupaten Banggai, 2013).

Memasuki wilayah dengan hukum adat serta kebiasaan yang berbeda dari penduduk lain mungkinkah kebiasaan-kebiasaan dari suku Bali transmigrasi mengalami degradasi budaya bertani. Arah akulturasi tersebut adanya perubahan pola pikir dan kebiasaan bertani masyarakat suku Bali akibat percampuran budaya masyarakat. Terkadang budaya yang dimiliki menjadi suatu titik konflik sosial antara suku pendatang dan pribumi.

Fakta tersebut menjadi satu problema dikalangan masyarakat suku bali transmigrasi. Penyesuaian diri bagi sebagian masyarakat terkadang sangat sulit dilakukan sehingga tindakan yang diambil adalah dengan kembali ke daerah asli mereka berasal. Bagi suku Bali yang menetap di daerah transmigrasi mereka berusaha untuk dapat beradaptasi dengan kondisi itu. Lambat laun bahwa tradisi yang mereka anut dari Bali akan terjadi perubahan yang signifikan. Permasalahannya adalah masihkah masyarakat suku Bali di daerah transmigrasi menerapkan sistem bertani yang penuh dengan ritual serta tegakan bangunan sucinya, apakah irigasi subak dalam mengatur suplay dan pembagian air di lahan sawah dan kering 
masih dikenal oleh generasi sekarang. Atau, suku Bali transmigrasi tidak memahami lagi bagaimana pengaturan irigasi subak karena telah lamanya berada di daerah transmigrasi dengan kondisi pendahulu mereka telah tiada. Dengan sekian lamanya program transmigrasi tersebut dilakukan oleh pemerintah yang menyebabkan generasi muda Bali transmigrasi tidak dapat lagi mengenali budaya bertani nenek moyang mereka secara keseluruhan. Tentunya program ini menjadi suatu tantangan moral bagi petani yang bersuku Bali di daerah transmigrasi.

Bila dikaji akan terdapat beberapa perubahan kultur yang mungkin terjadi pada masyarakat suku Bali transmigrasi, yakni (1) masyarakat akan mempertahankan budaya daerah asalnya, (2) masyarakat akan meninggalkan budaya daerah asalnya, dan (3) akan terjadi modifikasi budaya yang mencampurkan antara budaya daerah asal dan budaya yang baru. Tentunya hal tersebut menjadikan sumber pengalaman baru dalam bertani dan juga merupakan suatu tantangan. Sutawan (2001), menambahkan tantangantantangan tersebut mungkin saja bisa menggoyahkan sendi-sendi kehidupan subak atau bahkan bisa mengancam eksistensinya apabila tidak dapat diupayakan solusinya agar tantangan-tantangan tersebut dapat dijadikan peluang bagi subak untuk memperkuat dan meningkatkan peranannya di masa-masa mendatang sesuai dengan perkembangan zaman. Adalah menjadi tugas dan tanggung jawab moral bagi kita semua untuk menyumbangkan pikiran bagaimana agar subak sebagai warisan budaya bangsa yang bernilai luhur dapat dilestarikan. Maksudnya bukan hanya mempertahankan nilai-nilai lama, tetapi sekaligus membina dan mengembangkan di mana unsur-unsur yang dipandang sudah tidak sesuai lagi dengan tuntutan masa kini maupun masa datang dapat dilakukan penyesuaian-penyesuaian sesuai kebutuhan. Tujuannya tidak lain agar subak menjadi lebih kuat dan mandiri dan anggotaanggotanya dapat lebih diberdayakan serta terangkat kesejahteraannya. Dengan demikian, subak menjadi tangguh menghadapi berbagai tantangan modernisasi.
Berdasarkan beberapa hal di atas, maka penelitian ini mengkaji tentang "Tata Kelola Subak pada Masyarakat Suku Bali Transmigrasi di Desa Duata Karya Kecamatan Masama Kabupaten Banggai".

\section{METODE PENELITIAN}

\section{Pendekatan dan Jenis Penelitian}

Penelitian ini didesain dengan menggunakan pendekatan survei, Pertimbangan pendekatan survei dilakukan didasarkan pada: (1) bahwa tradisi subak merupakan budaya yang telah ada dan dibawa dari Bali ke daerah transmigrasi, selanjutnya tradisi tersebut menjadi makna yang berarti baginya, makna itu diderivasi atau lahir dari tingkah laku dalam kehidupan mereka, yang kemudian melahirkan interpretasi yang dapat melahirkan suatu penjelasan. (2) bahwa manusia dalam konteks bertani saling berinteraksi dan membentuk organisasi adat dan atau struktur sosial, interaksi tersebut akan melahirkan suatu objek yang memiliki makna intrinsik dalam budaya bertani masyarakat Bali transmigrasi. Sebab masyarakat Bali identik dengan pemaknaan simbol-simbol yang mereka yakini memiliki makna sosial-religius dalam tradisi bertani mereka. Pemilihan ini dikaitkan dengan ideologi yang tertanam pada masyarakat Bali adalah kental dengan adat istiadatnya. Dari hal tersebut akan timbul pemikiran dari seorang masyarakat, dapat memandang pola sosial, serta timbul persepsi yang diwujudkan dalam bentuk tindakan-tindakan dalam kehidupan bertani masyarakat Bali transmigrasi. Serta (3) dari program transmigrasi tentunya akan menumbuhkembangkan pemahaman yang berbeda terhadap suatu polatatanan budaya yang terbawa dari Bali, dan akan berkolaborasi dengan budaya masyarakat pribumi, yang akan menimbulkan suatu modifikasi budaya baru. Budaya ini akan menjadi unik untuk diinterpretasikan sebab melahirkan pemahaman dan teoritik konkrit yang relevan dan terbarukan.

\section{Waktu dan Lokasi Penelitian}

Penelitian ini akan dilaksanakan selama 5 Bulan yakni pada Bulan Juni sampai Oktober 2017. Bertempat di Desa Duata 
Karya, Kecamatan Masama, Kabupaten Banggai, Provinsi Sulawesi Tengah. Desa Duata Karya dipilih menggunakan purposive method, artinya bahwa lokasi penelitian memang sengaja dipilih. Alasan memilih Desa Duata Karya ialah: (a) sebaran masyarakat Bali transmigrasi di daerah tersebut dominan bermata pencaharian menjadi petani, (2) tradisi bertani mengadopsi sistem subak dan kebiasaan masyarakat setempat masih kental dengan ritual keagamaannya yang diaktualisasikan pada pertanian, (3) pola bertani masyarakat Bali di daerah tersebut adalah dominan lahan sawah.

\section{Jenis dan Sumber Data}

Jenis data yang digunakan dalam penelitian ini adalah data kuantitatif dan kualitatif. Sumber data penelitian terdiri dari data primer dan data sekunder. Data primer tersebut adalah murni didapat dari hasil wawancara lapangan dengan penuntun kuesioner yang telah disediakan. Sedangakan data sekunder adalah data-data yang mendukung penelitian ini seperti dokumendokumen organisasi adat subak, literaturliteratur penunjang yang terfokus pada subak, serta dokumen bendesa adat/ Desa/kelurahan.

\section{Populasi dan Teknik Penarikan Sampel}

Populasi merupakan masyarakat tani yang melakukan pengelolaan irigasi dengan sistem subak, dan tokoh masyarakat yang mengetahui budaya subak. Sampel ditentukan secara sengaja dengan pertimbangan bahwa responden merupakan pelaku utama yang tergabung dalam kelompok subak di Desa Duata Karya. Sampel yang ditentukan berjumlah 9 responden yang terdiri dari 7 orang dari kelompok subak, dan 2 orang tokoh adat/ masyarakat.

\section{Pengeumpulan data}

Dalam penelitian ini beberapa teknik pengumpulan data yang dilakukan, yaitu: observasi, wawancara dan dokumenter. Kegiatan observasi dilakukan dengan penjelajahan lokasi penelitian dan mencari informasi awal tentang irigasi yang diterapkan pada masyarakat Bali transmigrasi. Kegiatan wawancara dilakukan dengan mengajukan pertanyaan kepada masyarakat dengan kuesioner yang telah disiapkan. Serta kegiatan dokumenter dilakukan untuk mendokumentasikan segala bentuk kegiatan dalam penelitian.

\section{Analisis Data}

Analisis data dalam penelitian ini menggunakan analisis deskripsi, yakni mendeskrisikan sistem tata kelola irigasi subak pada masyarakat suku bali tranasmigrasi di Desa Duata Karya. Ada beberapa langkah yang dilakukan dalam analisis data yaitu: mengklasifikasikan dan koding data, interpretasi data, pengecekan keabsahan data, deskripsi data penelitian, dan penyajian data.

\section{HASIL DAN PEMBAHASAN}

\section{Pemahaman terhadap Irigasi Subak}

Irigasi adalah usaha penyediaan, pengaturan, dan pembuangan air irigasi untuk menunjang pertanian yang jenisnya meliputi irigasi permukaan, irigasi rawa, irigasi air bawah tanah, irigasi pompa, dan irigasi tambak. Sistem irigasi meliputi prasarana irigasi, air irigasi, manajemen irigasi, kelembagaan pengelolaan irigasi, dan sumber daya manusia (PP Republik Indonesia Nomor 20 Tahun 2006). Sistem irigasi merupakan suatu metode konservasi tanah dan air. Irigasi diutamakan dalam pemberian air kepada tanah untuk memenuhi kebutuhan air bagi pertumbuhan tanaman (Arsyad, 2006; 2010; Hardjowigeno, 2010; Mawardi, 2011). Berbagai bentuk irigasi dikenal pada umumnya oleh masyarakat, namun pada masyarakat suku Bali pengaturan irigasi dikenal dengan sistem "Subak".

Subak adalah organisasi kemasyarakatan yang mengatur sistem pengairan sawah, yang digunakan untuk bercocok tanam padi di Bali (Satria et al., 2017). Selanjutnya Lestari et al., (2015), menyatakan bahwa subak adalah kelompok yang mengkoordinasikan sistem pengaturan dan penggunaan air di Bali. Sesuai dengan Peraturan Daerah Bali tahun 2012, bahwa Subak adalah organisasi tradisional dibidang tata guna air dan atau tata tanaman di tingkat usaha tani pada masyarakat adat di Bali yang bersifat sosioagraris, religius, ekonomis yang secara historis terus tumbuh dan berkembang. Tujuan dari Subak mencakup: (a) memelihara 
dan melestarikan organisasi subak; (b) mensejahterakan kehidupan petani; (c) mengatur pengairan dan tata tanaman; (d) melindungi dan mengayomi petani; dan (e) memelihara serta memperbaiki saluran air ke sawah.

Dalam Peraturan Daerah Provinsi Bali No. 02/PD/DPRD/1972 dalam Sumiyati e al., (2011), dinyatakan bahwa subak adalah suatu masyarakat hukum adat yang memiliki karakteristik sosio-agraris-religius, yang merupakan perkumpulan petani yang mengelola air irigasi di lahan sawah. Subak tidak hanya terbatas pada organisasi pengelolaan air dan jaringan irigasi, namun berkaitan erat pada produksi pangan, ekosistem lahan sawah beririgasi, dan ritual keagamaan yang terkait dengan budidaya padi (Aryawan et al., 2013). Setiyanto (2012), mengatakan bahwa subak adalah organisasi yang mengatur pembagian pemanfaatan air untuk mengairi sawah pada areal tertentu. tiap subak memiliki nama tersendiri dan mempunyai sejumlah anggota yang disebut krama subak, mempunyai pengurus yang disebut prajuru subak yang dipimpin oleh seorang pekaseh (klian subak).

\section{Konsep Subak}

Sistem irigasi Subak menganut konsep Tri Hita Karana (THK) (Lihat Gambar 1). Konsep Tri Hita Karana adalah salah satu ajaran dalam agama Hindu yang pada intinya mengajarkan tentang keseimbangan antara manusia dengan Tuhan, manusia dengan manusia, dan manusia dengan lingkungannya. Ketiga keseimbangan tersebut merupakan penyebab terjadinya kebahagiaan. Sebagai salah satu ajaran, Tri Hita Karana selalu dijadikan landasan filosofis dalam pembangunan, baik pembangunan di tingkat daerah maupun pembangunan di tingkat desa (Astiti, 2011). Demikian pula dalam budaya bertani, konsep ini selalu menjadi pedoman.

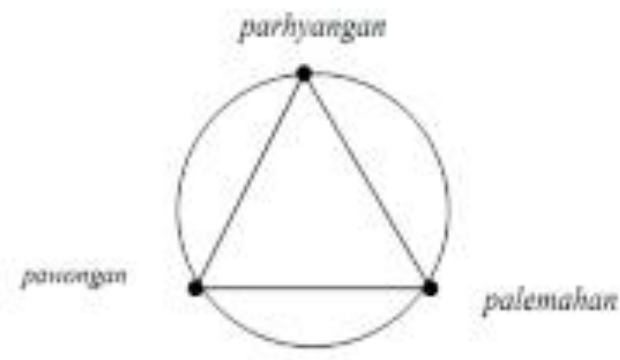

Gambar 1. Hubungan timbal-balik antar komponen Tri Hita Karana (THK) (Sumber: Windia, 2012)

Hubungan tersebut dijabarkan dalam wujud adalah: (1) hubungan "vertikal ke atas" yakni hubungan antara manusia dengan Tuhan Yang Maha Esa, yakni diaplikasikan dengan adanya "Parhyangan" (tempat persembahyangan). Setiap Subak mempunyai pura (tempat persembahyangan) tersendiri yang disebut Pura subak, sebagai unsur Ketuhanan di dalam subak itu sendiri, (2) hubungan "horizontal" yaitu antara manusia dengan sesama manusia yang kemudian diaplikasikan dengan pawongan/perumahan. Pada sistem subak mempunyai anggotaanggota yang disebut krame subak atau dibeberapa tempat disebut krame carik , sebagai unsur kemasyarakatan. Hubungan ini misalnya dalam melakukan rapat-rapat, gotong royong serta rasa kebersamaan yang harmonis diantara anggota subak, dan (3) hubungan "vertikal ke bawah" yakni hubungan dengan alam semesta (lingkungan) yang diwujudkan ke dalam palemahan. Palemahan berasal dari kata lemah yang berarti tanah, alam, bumi atau wilayah. Dengan hubungan yang harmonis serta memelihara dengan baik alam ini, petani akan mencapai ketentraman (Sunaryasa, 2002).

Tinjauan subak sebagai sistem teknologi dari suatu sosio-kultural masyarakat, menyimpulkan bahwa sistem irigasi (termasuk subak) merupakan suatu proses transformasi sistem kultural masyarakat yang pada dasarnya memiliki tiga subsistem yakni: (i) subsistem budaya (pola pikir, norma dan nilai); (ii) subsistem sosial (termasuk ekonomi); dan (iii) subsistem kebendaan (termasuk teknologi). Semua subsistem itu memiliki hubungan timbal- 
balik, dan juga memiliki hubungan keseimbangan dengan lingkungannya seperti terlihat dalam Gambar 2 (Arif, 1999).

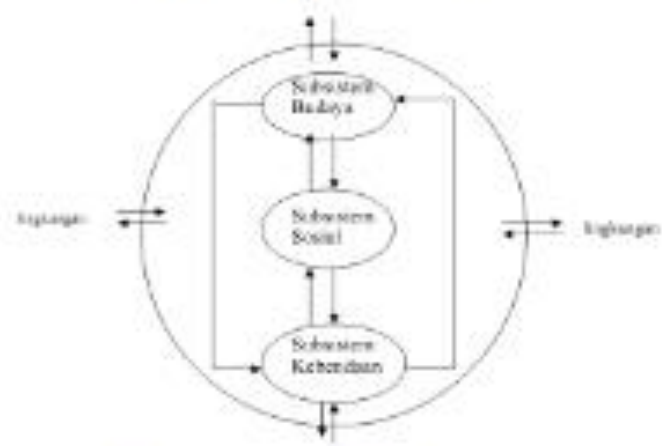

Gambar 2. Hubungan timbal balik antar subsistem dalam sistem manajemen irigasi masyarakat yang bersifat sosio-kultural (Sumber: Arif, 1999)

Hubungan sosial yang sangat harmonis selalu ditunjukkan oleh masyarakat subak. Seperti halnya dilaporkan oleh Suwena (2012) dalam Subak Muwa, Solidaritas sosial yang dapat dilihat selama proses pengolahan tanah pertanian adalah dalam kegiatan tolongmenolong dan gotong-royong para petani dalam mengerjakan sawah dari awal sampai panen padi berlangsung. Serta pengaturan pengairan tradisional memegang peranan utama dalam kelangsungan kehidupan pertanian lahan basah. Jelantik (2006), Subak sebagai organisasi yang fungsi utamanya adalah mengatur air irigasi telah membangun sistem jaringan irigasi dengan keunggulan teknologi tradisionalnya, dimana konstruksi jaringan sangat disesuaikan oleh kondisi fisik alam dimana jaringan itu dikonstruksi. Jaringan irigasi subak sudah dikonstruksi sedemikian lengkap mulai dari bangunan pengambilan pada sumber air, bangunan pembagi dan pengambilan di saluran sampai saluran distribusi di petak-petak sawah. Pembagian Wilayah Subak dalam Wilayah Desa Adat seperti ditunjukkan dalam gambar 3, dan jaringan irigasi subak pada Gambar 4. Hubungan elemen-elemen dalam sistem irigasi subak yang berlandaskan THK sangat komplek yang sebagian diantaranya mengandung nilai-nilai kuantitatif, misalnya pada elemen-elemen yang bersifat kebendaan, dan sebagian lainnya mengandung nilai-nilai kualitatif, misalnya, pada elemen-elemen yang bersifat pola pikir dan sosial (Windia et al., 2011).

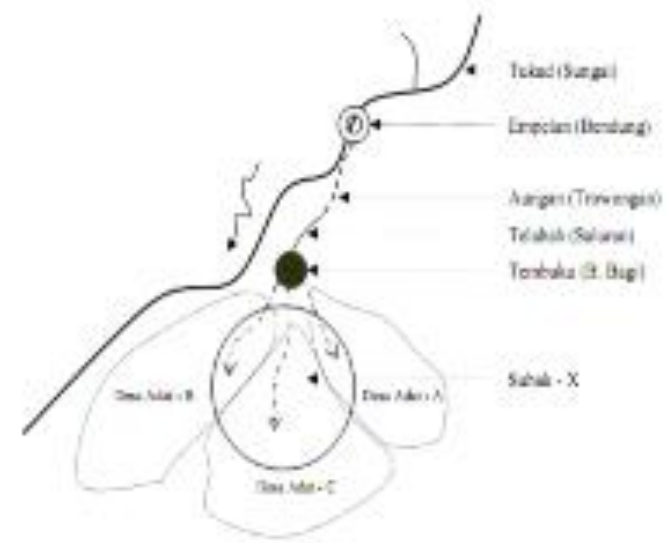

Gambar 3. Ilustrasi Wilayah Subak dalam Wilayah Desa Adat

Suradisastra dan Dariah (2002). menambahkan kekuatan budaya tradisional masyarakat petani adalah pada dasamya budaya bertani dengan teknologi zero-input atau near-zero-input, yang menghasilkan tingkat produktivitas rendah, namun dengan sustainabilitas tinggi. Namun, menurut Kohdrata dan Sutrisna (2011), seringkali eksistensi Subak terkesampingkan dari perhatian terutama dari dari aspek intangible. Padahal sebagaimana yang telah disebut dalam paragraf sebelumnya, bahwa aspek tangible dan intangible merupakan satu unit yang utuh.

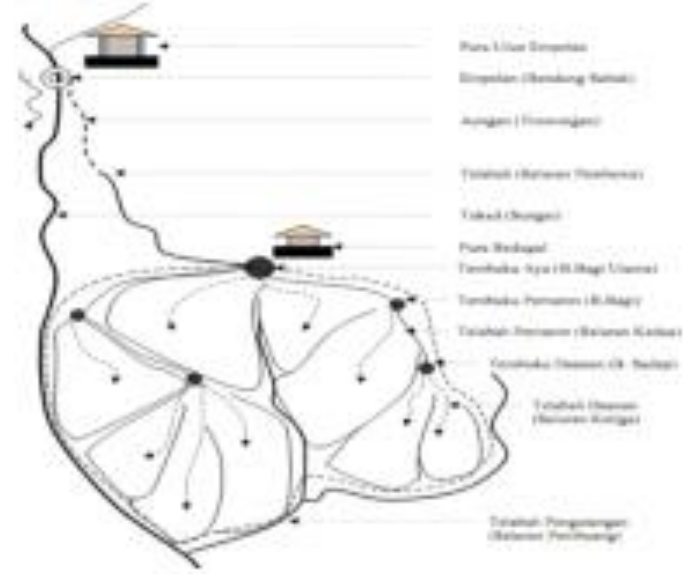
Gambar 4. Jaringan Irigasi Subak (Sumber: Jelantik, 2006)

\section{Keberadaan Subak dan Distribusi Air di Desa Duata Karya}

Berdasarkan penuturan salah satu anggota kelompok tani subak bahwa subak di Desa Duata Karya sendiri terbentuk pada 
tahun 1974. Desa ini merupakan Desa yang penduduknya adalah masyarakat transmigrasi, dulunya belum ada sistem pengairan lahan persawahan untuk bercocok tanam, sehingga masyarakat berinisiatif membentuk kelompok pengguna air (subak) untuk mengatur jalannya pengairan air ke lahan sawah.

Petani Desa Duata Karya merupakan petani yang sebagian besar memiliki lahan sawah. Dalam aktivitas lahan sawah, tentu sangat membutuhkan banyak air untuk pertumbuhan padi. Sumber air yang digunakan berasal dari sungai Waru. Dalam pengelolaanya, untuk menyalurkan air secara merata ke seluruh lahan sawah petani, sebelum disalurkan ke lahan masing-masing petani, di tampung terlebuh dahulu. Alur masuknya air ke lahan sawah petani adalah dari "free intake"/sungai utama, kemudian dialirkan ke saluran irigasi melalui pintu pembagian air dan mengalir ke masingmasing saluran sekunder dan tersier hingga ke petak-petak sawah petani (Gambar 5). Pengelolaan subak ini memiliki 7 pintu air yang nantinya akan diteruskan ke masingmasing lahan (Gambar 6). Dalam pintu air terdapat beberapa pembuangan air yang tujuannya ialah untuk mengatur volume air agar tidak terjadi kelebihan air yang masuk ke petak sawah. Di petak sawah juga terdapat saluran pembuangan air atau SPA yang bertujuan untuk membuang air yang berlebih di petak sawah ketika seluruh sawah petani telah terairi.

Pada umumnya pembagian air dari sungai ke subak-subak dan dari subak ke tempek-tempek dan selanjutnya dari tempektempek ke petak-petak sawah para anggota subak di sesuaikan dengan luas sawah dimasing-masing subak, tempek dan petak. Pembagian air memperhatikan keseimbangan antara volume air dan luas sawah dimasingmasing subak. Hal ini dilakukan untuk menjaga jangan sampai terjadi kelebihan dan kekurangan air yang berdampak bagi tanaman (Setiyanto, 2012).

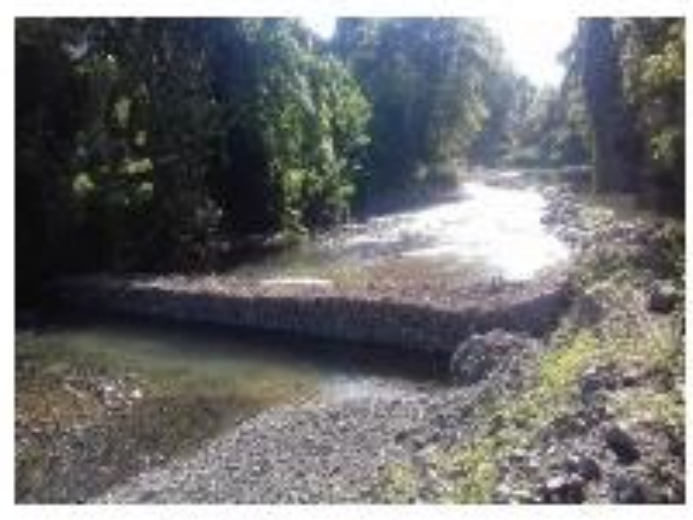

Gambar 5. Sungai utama (free intake) (Sumber: Dokumentasi Penelitian)
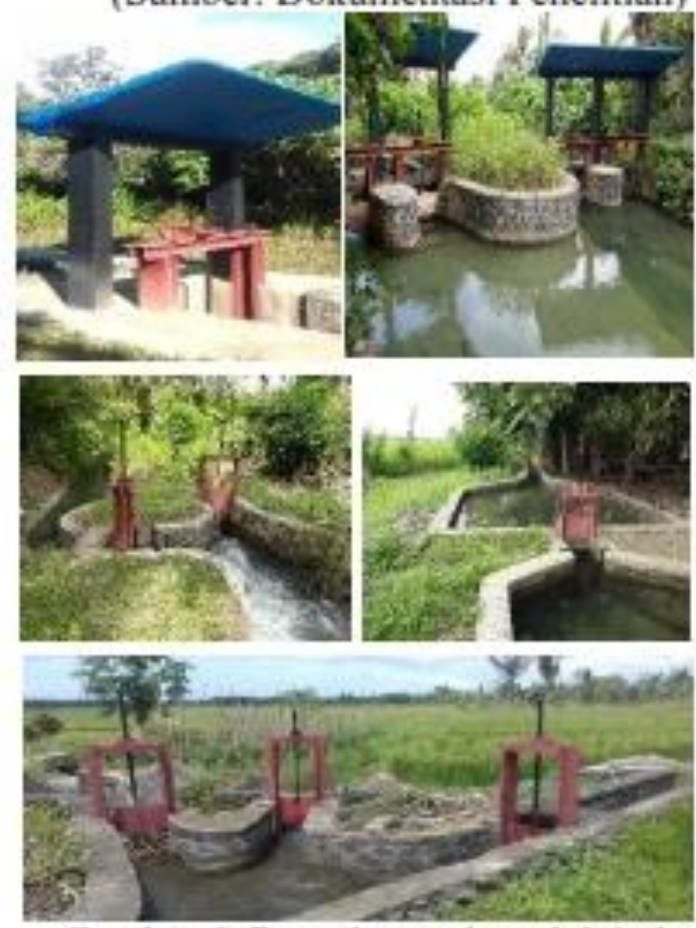

Gambar 6. Penyaluran air melalui pintupintu air dalam pengelolaan irigasi subak di Desa Duata Karya (Sumber: Dokumentasi Penelitian)

\section{Pengelolaan Irigasi Subak}

Pengelolaan subak terdiri atas aspek fisik dan non fisik. Gatra fisik ditandai dengan adanya jaringan irigasi (bangunan dan saluran irigasi), seperti bendung (empelan), terowongan, jaringan utama (saluran primer dan sekunder), bangunan bagi, bangunan bagi sadap, dan lain sebagainya) serta fasilitas irigasi, seperti pintu air, selain fisik sawahsawah dalam persubakan (Pradnyawathi dan Adnyana, 2013). Sedangkan aspek non-fisik 
merupakan organisasi yang mengkoordinir yang selanjutnya disebut dengan subak.

\section{Aspek Fisik}

Secara umum aspek fisik dalam unit pelayanan wilayah subak meliputi areal sawah, jaringan dan bangunan. Dalam suatu unit subak, jaringan pelayanan irigasinya dimulai dengan empelan (bendung) pada ruas sungai. Kemudian pada satu atau kedua sisi ruas sungai dapat dibuat bangunan pintu pemasukan air yang disebut buka (intake), yang dilanjutkan dengan saluran air yang disebut telabah (saluran primer). Pada unit subak, empelan merupakan wilayah hulu yang ditandai oleh adanya bangunan suci yang disebut Pura Ulun Empelan (Sumarta, 1992) dalam (Pradnyawathi dan Adnyana, 2013).

\section{a. Pengelolaan Sumberdaya Air}

Sistem pengelolaan air sendiri dilakukan dengan cara koordinasi antara pekaseh dengan ketua kelompok tani, selanjutnya ketua meneruskan kepada anggota-anggotanya. Sumber air untuk irigasi subak umumnya bersumber dari aliran sungai atau mata air, dialirkan melalui pengambilan bebas ke saluran (telabah) atau terowongan (aungan) (Norken, 2016). Berdasarkan hasil wawancara langsung dengan petani sumber air untuk irigasi yang digunakan berasal dari sungai Waru. Cara pembagian air ke masingmasing petak sawah petani disesuaikan dengan luas lahan yang dimiliki petani atau disesuaikan dengan kebutuhan. Karena kelangkaan sumberdaya air diindikasikan juga oleh terjadinya konflik perebutan air antar petani maupun antar sektor (Pasandaran, 2005; Saptomo, 2006 dalam Tarigan et al,, 2013).

Proses pembagian air dilakukan melalui free intake atau sungai utama, yang dialirkan melalui empelan (bendungan kecil) (Gambar 7), setelah itu diteruskan ke pintu air pertama yang selanjutnya akan disalurkan ke saluransaluran tradisional petani (Gambar 8) untuk diteruskan ke sawah-sawah petani. Pintu yang digunakan untuk menyalurkan air ke saluran petani berjumlah 7 pintu, sehingga memudahkan proses distribusi air sampai ke lahan-lahan sawah melalui saluran-saluran kecil. Air yang diterima oleh petani dengan sistem bergilir dengan pembagian nya melalui tempek dan terbagi menjadi subak kauh dan subak kangin. Pengelolaan irigasi ini terjadi secara natural dan akan terbagi merata ke lahan sawah petani, sehingga sangat jarang ditemui konflik sosial yang terjadi dalam pembagian air untuk padi sawah petani.

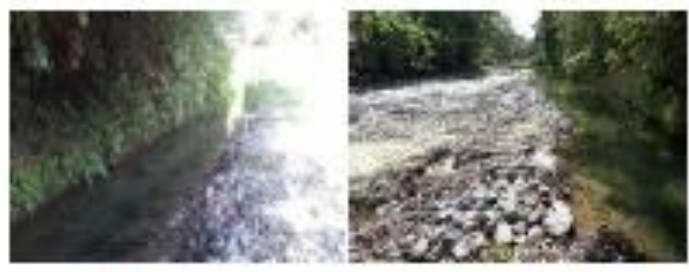

Gambar 7. Empelan air pada sungal waru (Sumber: Dokumentasi Penelitian)

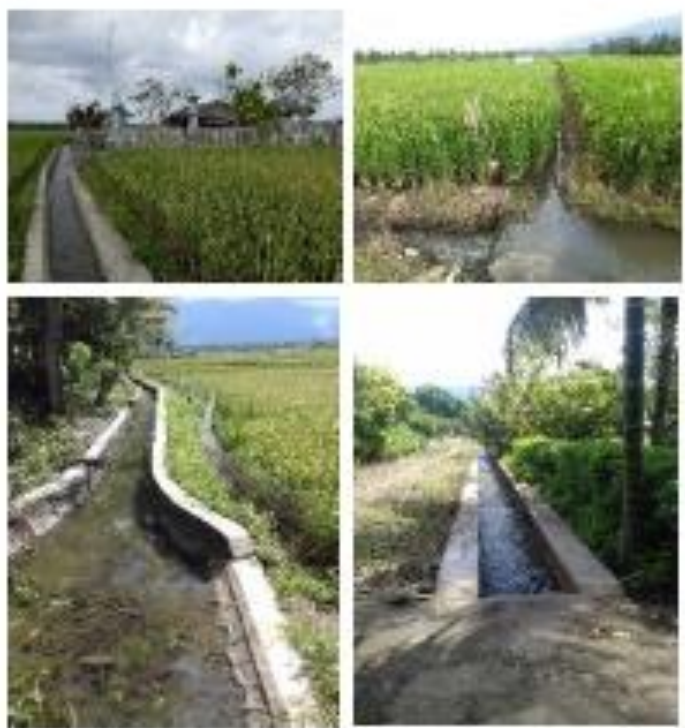

Gambar 8. Saluran-saluran Irigasi yang menyalurkan air sampai ke sawah (Sumber: Dokumentasi Penelitian)

Pada pengelolaannya, sistem irigasi juga banyak menemui kendala teknis. Seperti Dilaporkan oleh Aditya et al., (2013), kendala tersebut: (1) saluran irigasi yang rusak, (2) hama kepiting, (3) sampah, dan (4) pendangkalan sungai. Kerusakan saluran irigasi menyebabkan distribusi air terhambat. b. Pengelolaan Bangunan Suci dan Jaringan Irigasi

Bangunan disini dalam artian adalah bentuk fisik dari perangkat sistem subak yang digunakan oleh anggota untuk mengairi sawah maupun upacara adat sebelum waktu tanam dan waktu panen. Bangunan yang dikelola oleh subak Desa Duata Karya antara lain pura suci yaitu pura ulun suwi (Gambar 
9), pura bedugul (Gambar 9), empelan, free intake, aungan, telabah gede dan cenik, dan lainnya. Berdasarkan hasil wawancara dengan anggota kelompok tani subak, di Desa Duata Karya empelan yang dimiliki berjumlah 1 empelan (Gambar 7). Selanjutnya, pada akhir dari telabah (saluran primer) ini, terdapat bangunan bagi yang disebut tembuku aya (bangunan bagi sekunder), demikian selanjutnya diikuti dengan saluran yang disebut telabah pemaron (saluran sekunder) sampai pada areal sawah (Gambar 8).
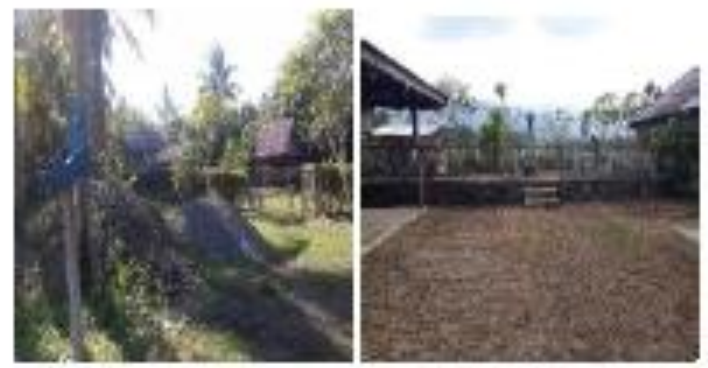

Gambar 9. Keberadaan Pura Ulun Suwi (Kiri), dan Pura Bedugul (Kanan) di Desa

Duata Karya (Sumber: Dokumentasi Penelitian)

Pura ulun suwi menurut masyarakat setempat ialah pura yang terletak paling atas atau hulu, sebagai pusat atau sumber kemakmuran dalam usahatani sawah. Di pura inilah para masyarakat tani melakukan persembahyangan memohon anugerah dan kemakmuran untuk tanaman petani baik di sawah/lahan basah maupun di lading/lahan kering. Dikatakan pula bahwa dengan adanya pura ulun suwi ini memberikan dampak yang baik terhadap kemakmuran usahatani masyarakat di desa duata karya. Sedangkan Pura bedugul menurut tokoh masyarakat ialah pura yang terletak di tengah-tengah persawahan masyarakat. Sebelum melakukan penanaman dan pemanenan padi masyarakat desa melakukan persembahyangan untuk memohon anugerah kemakmuran kepada Tuhan.

Dalam pengelolaan bangunan subak misalnya free intake dan empelan dilakukan dengan cara membersihkan sampah/seresah yang menghalangi aliran air dan menjadi masalah pada proses pengairan, dan menjaga agar tidak menghambat pengairan sawah petani. Seperti saluran dan pintu tempat mengalirnya air agar tetap berjalan tanpa ada hambatan apapun saat musim tanam tiba. Pengelolaan irigasi sistem subak dilakukan dengan cara gotong royong antara anggota kelompok tani. Adapun pengelolaan pura bedugul dilakukan untuk menjaga agar proses upacara adat yadnya yang dilakukan sebelum tanam dan panen padi sebagai bentuk rasa syukur umat Hindu terhadap sumberdaya alam.

Sedangkan jaringan irigasi yang berada di Desa Duata Karya terdiri atas irigasi primer, sekunder dan tersier. Irigasi ini digunakan untuk meneruskan air yang berasal dari sumber air utama, melalui 7 pintu yang disebutkan sebelumnya. Pengelolaan jaringan irigasi ini dilakukan dengan cara kerjabakti mingguan oleh kelompok-kelompok tani untuk tetap menjaga kebersihan irigasi.

c. Kondisi Bangungan dan Jaringan Air

Berdasarkan hasil penelitian, kondisi bangunan dan jaringan air subak di Desa Duata Karya cukup memadai. Namun, kadang masih mengalami beberapa permasalahan atau kerusakan, misalnya pada saat musim penghujan sering terjadi banjir yang dapat menyebabkan tersumbatnya free intake oleh pasir dan batu. Penuturan yang sama juga di katakan oleh salah satu anggota subak, apabila banjir besar empelan bisa saja jebol karena tidak mampu menahan debit air. 2. Aspek Non-Fisik

a. Organisasi dan Kelembagaan

Struktur dasar kepengurusan subak sangat sederhana, namun terbagi menjadi subak kecil dan subak besar. Sederhananya struktur subak hanya terdiri dari PekasehKelian-Kesinoman-Krama/anggota subak. Menurut Pitana (1993) dalam Norken (2016) menguraikan, untuk subak yang kecil hanya dipimpin oleh seorang ketua yang disebut kelihan subak atau pekaseh. Sedangkan untuk subak lebih besar maka prajuru terdiri dari: Pekaseh (ketua), Petaju (wakil ketua), Penyarikan atau juru tulis (sekretaris), Patengen atau juru raksa (bendahara), Kasinoman atau juru arah (penyalur informasi) dan Saya (pembantu khusus berkaitan dengan kegiatan keagamaan). Untuk subak yang sangat besar atau 
beberapa subak yang bersumber dari satu bendung disebut subak gede, dan dipimpin oleh pekaseh gede dan wakil pekaseh gede.

Anggota subak adalah masyarakat petani yang notabenenya memiliki lahan basah (sawah). Di Desa Duata Karya sendiri memiliki 7 kelompok tani subak yang terbentuk dengan anggota masing-masing 21 25 orang dengan struktur sebagai berikut (Gambar 10).

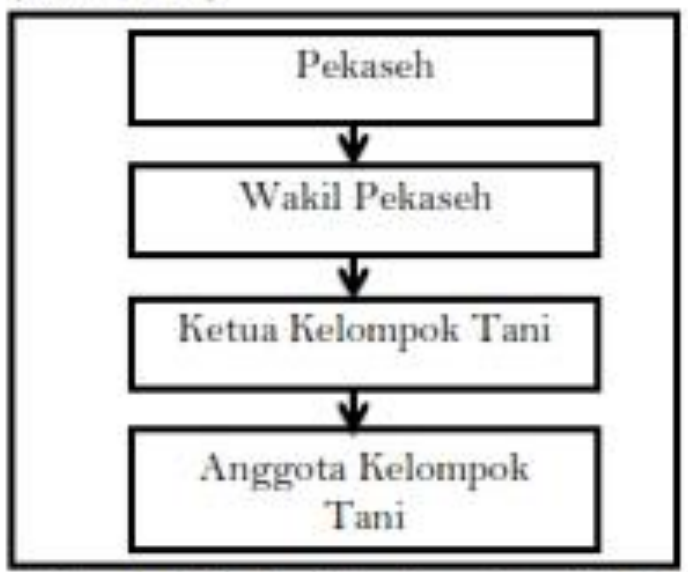

Gambar 10. Struktur Organisasi Subak di Desa Duata Karya

Pekaseh merupakan pimpinan subak. Menurut Artha (2016), pekaseh adalah ketua subak yang mempunyai kewajiban memimpin suatu subak. Berdasarkan hasil wawancara dengan anggota subak tugas pokok pekaseh antara lain; 1) mengatur sistem irigasi, 2) mengatur sistem pelaksanaan upacara adat pertanian (yadnya), 3) menentukan jadwal penanaman padi, 4) mengkoordinasi kelompok tani pemakai air. Artha (2016), menambahkan bahwa dalam kesehariannya pekaseh akan bertugas memimpin rapat-rapat subak, yang materi rapat dapat berupa penetapan peraturan subak, pengaturan pembagian air, penanganan konflik/sengketa jika ada, pengaturan upacara keagamaan yang terkait dengan subak, termasuk melakukan koordinasi dengan pihak-pihak lain (lembaga) di tingkat desa dan kecamatan agar supaya subak dapat melaksanakan peran/ fungsinya dengan baik.

Di Desa Duata Karya pengurus berperan sesuai dengan tupoksi masingmasing. Pergantian pengurus subak umumnya tidak mempunyai ketentuan yang pasti, namun belakangan setelah subak-subak memiliki "awig-awig" yang telah disahkan masa bakti kepengurusan subak telah ditentukan, yaitu 5 tahun dan dapat dipilih kembali. Pemilihan pengurus tentunya melalui rapat subak yang dipimpin oleh Ketua subak (pekaseh) dengan dasar musyawarah mufakat (Artha, 2016). Agar mampu berperan ganda, subak perlu melaksanakan restrukturisasi kelembagaan untuk menempatkan unit agribisnis secara legal dalam struktur organisasi subak (Budiasa, 2010).

Di Desa Duata Karya sendiri pergantian pengurus atau pemilihan pekaseh yang baru dilakukan dengan cara musyawarah mufakat dengan ketentuan melihat kemampuan calon pekaseh dalam memimpin organisasi. Apabila musyawarah tidak menjumpai kesepakatan, maka keputusan diambil melalui sistem vooting. Di Desa Duata Karya pekaseh juga memperoleh insentif yang diberikan dalam kurun waktu 6 bulan sekali atau setelah panen.

b. Pengelolaan Regulasi/aturan yang berlaku pada sistem subak

Regulasi atau peraturan yang mengatur subak secara internal disebut awig-awig. Awig-awig adalah peraturan yang mengatur berbagai kegiatan, organisasi, hak dan kewajiban anggota para subak tersebut. Awig-awig dapat diperluas dan ditambahkan dengan aturan tambahan, disebut pasuara (aturan tambahan) (Norken, 2016). Adapun hak dan tanggung jawab yang dilakukan oleh pengelola subak antara lain, pengelola berhak memperoleh upah/ insentif setiap 6 bulan sekali. Sedangkan tanggungjawab pengelola adalah mengkoordinasi setiap elemen seperti ketua kelompok (munduk) untuk mengatur distrisbusi air, menentukan waktu tanam dan panen padi.

Semua elemen kesubakan turut berperan aktif dalam pengelolaan subak. Mulai dari ketua kelompok dan anggota kelompok tani, hingga apparat desa juga turut berperan aktif. Peran ketua kelompok tani antara lain mengatur masuknya air ke masingmasing anggota kelompok tani, sedangkan peran anggota kelompok adalah ikut gotong 
royong membersihkan saluran irigasi setiap musim tanam. Sedangkan aparat desa ikut membantu dan bekerja sama dengan pekaseh dalam pembuatan aturan-aturan yang mengatur anggota kelompok tani dalam pembagian air dan juga membantu dalam pembuatan RDKK (rencana dasar kegiatan kelompok).

\section{Implikasi terhadap Ekonomi Masyarakat}

Berdasarkan hasil wawancara dengan petani, dengan adanya subak ini mampu meningkatkan hasil produksi pertanian yang berdampak pada kesejahteraan masyarakat. Apalagi saat ini BUMDES juga turut berperan dalam meningkatkan perekonomian masyarakat Desa sehingga perputaran dana masih terus jalan.

Selain itu sangat terlihat perbedaan dari sebelum ada peraturan subak dengan setelah ada peraturan subak. Sebelum ada aturan subak sering terjadi konflik antar pengguna air irigasi, setelah ada aturan subak, konflik tersebut berkurang. Pada dasarnya dengan adanya subak di daerah transmigrasi, sangat menguntungkan petani sawah dari segi perekonomian.

\section{Implikasi terhadap Pelestarian Budaya}

Implikasi yang diberikan dengan adanya sistem subak ini bukan hanya dari segi ekonomi, melainkan juga berpengaruh terhadap sosial budaya masyarakat. Karena seperti yang diketahui bahwa subak ini merupakan budaya dari masyarakat Hindu Bali. Berdasarkan hasil wawancara dengan petani subak, budaya yang sering dilakukan dalam sistem subak antara lain melakukan upacara yadnya (ngawiwet) pada saat sebelum tanam, dan upacara yadnya (mesaba) saat sebelum panen padi dan menanam pohon di bantaran sungai. Pelestarian budaya ini sangat didukung oleh anggota kelompok dan masyarakat lain. Dengan adanya subak, masyarakat merasakan manfaat misalnya mempermudah jalannya budaya yadnya, dan menjaga kelestarian budaya umat Hindu. Karena semua elemen mendukung adanya sistem subak, maka kendala dalam pelestarian budaya tidak ada hambatan apapun, selain itu mayoritas masyarakat Desa Duata Karya merupakan pemeluk agama Hindu.
Keuntungan dari adanya sistem subak ini banyak dirasakan oleh masyarakat Desa Duata Karya antara lain penentuan jadwal tanam padi dan panen padi dapat dilakukan dengan tepat, begitupun dengan upacara yadnya yang menjadi budaya bali sebelum melakukan usaha pertanian mudah dilakukan. Selain keuntungan yang diperoleh dari sistem subak, yang namanya budaya dari leluhur atau tradisi tertantang dengan adanya moderninasasi zaman. Untuk menghadapi tantangan moderninasi ini salah satu hal yang harus dilakukan adalah tetap mempertahankan arela pertanian agar tidak mengalami land reform atau alih fungsi lahan.

\section{PENUTUP}

\section{Kesimpulan}

Hasil penelitian menunjukkan bahwa: (1) Pengelolaan organisasi kesubakan di Desa Duata Karya yakni pekaseh, wakil pekaseh, ketua kelompok tani dan anggota kelompok, yang memiliki tupoksinya masing-masing, dan (2) Pengelolaan subak dikelompokkan menjadi pengelolaan fisik, meliputi pengelolaan sumberdaya air, pengelolaan bangunan irigasi (empelan, aungan, pintu air pembagi, telabah gede, telabah cenik), juga pengelolaan terhadap bangunan pura ulun suwi dan pura bedugul. Sedangkan pengelolaan non fisik meliputi organisasi dan kelembagaan, serta pengelolaan regulasi/awig-awig kesubakan. Hal ini secara empiris sistem subak berimplikasi pada pemerataan pembagian air irigasi ke lahan sawah petani. Secara berkelanjutan sistem subak berimplikasi kepada peningkatan ekonomi dan pelestarian budaya lokal masyarakat, khususnya masyarakat suku Bali transmigrasi.

\section{Saran}

Perlu dilakukan pendampingan terhadap desa adat dalam pengelolaan subak oleh pemerintah, agar keajegan sistem irigasi subak di daerah transmigrasi selalu terjaga sebagai suatu warisan budaya pertanian yang berbasis sosio-agraris-religius. 


\section{DAFTAR PUSTAKA}

Aditya, P.A, Sudarma, I.M. \& Djelantik, A.A.A. (2013). Analisis Harga Air untuk Irigasi Padi Sawah di Wilayah Perkotaan (Kasus Subak Pakel I dan Subak Pagutan Kota Denpasar). Jurnal Agribisnis dan Agrowisata, 2(2), 46-52.

Arif, S.S. (1999). Penerapan Filsafat Tri Hita Karana dalam Desain dan Manajemen Sistem Irigasi Subak dalam Sebuah Studi Subak sebagai Adat Budaya, Sosial, dan Teknologi Sistem untuk Membangun budaya Pengelolaan Sumber Daya Air secara Terpadu. Yogyakarta: Fakultas Teknologi Pertanian, Universitas Gadjah Mada.

Arsyad, S. (2006). Konservasi Tanah dan Air. Bogor: IPB Press.

Arsyad, S. (2010). Konservasi Tanah dan Air. Edisi Ke 2. Bogor: IPB Press.

Artha, LN. (2016). Struktur Organisasi Subak di Bali. Makalah. Denpasar: Universita Udayana.

Aryawan, I.P.S., Windia, W., \& Wijayanti, P.U. (2013). Peranan Subak dalam Aktivitas Pertanian Padi Sawah (Kasus di Subak Dalem, Kecamatan Kerambitan, Kabupaten Tabanan). Jurnal Agribisnis dan Agrowisata, 2(1): $1-14$.

Astiti, T.J.P, Windia, W., Sudantra, I. K., Wijaatmaja, I.G.M., \& Dewi, A.A. (2011). Implementasi Ajaran Tri Hita Kanana Dalam Awig-Awig. Denpasar: Fakultas Hukum, Universitas Udayana, Riset Unggulan, 28-33.

Badan Pusat Statistik Kabupaten Banggai. (2011). Kabupaten Banggai dalam Angka.

Badan Pusat Statistik Kabupaten Banggai. (2013). Kabupaten Banggai dalam Angka.

Budiasa, I.W. (2010). Peran Ganda Subak untuk Pertanian Berkelanjutan di Provinsi Bali. Jurnal AGRISEP, 9(2), $153-165$
Jelantik S. (2006). Subak Dimasa Lalu Kini dan Nanti (Makalah Seminar Subak). Kabupaten Badung.

Kohdrata, N., \& Sutrisna, P.E. (2011). Konservasi Subak Anggabaya: Suatu Model Konservasi Lanskap Bali. Jurnal Lanskap Indonesia, 3(1), 4246.

Lestari, P.F.K., Windia, W., \& Astiti, N.W.S. (2015). Penerapan Tri Hita Karana untuk Keberlanjutan Sistem Subak yang Menjadi Warisan Budaya Dunia: Kasus Subak Wangaya Betan, Kecamatan Penebel, Kabupaten Tabanan. Jurnal Manajemen Agribisnis, 3(1): 22-34.

Norken, I.N. (2016). Manajemen Subak: Permasalahan dan Upaya Pemecahannya. Denpasar: Universitas Udayana.

Peraturan Daerah Provinsi Bali Nomor 02 Tahun 1972, Tentang: Pengaturan Irigasi Subak. Bali. (Diakses, 10 Juni 2014).

Peraturan Daerah Provinsi Bali Nomor 9 Tahun 2012, Tentang: Subak. Bali. (Diakses, 10 Juni 2014).

Peraturan Pemerintah Republik Indonesia Nomor 20 Tahun 2006, Tentang: Irigasi. Diunggah di: http:// www.bpkp.go.id/uu/filedownload/4/5 9/828.bpkp (Diakses, 10 Juni 2014).

Pradnyawati, N.L.M., \& Adnyana, G.M. (2013). Pengelolaan Air lrigasi Sistem Subak. DwijenAGRO. 3(2), 1-6.

Sari, N.M.E.P. (2013). Keberadaan Pura Bedugul di Subak Gebang Gading Atas Desa Pakraman Tegal Mengkeb Kecamatan Selemadeg Timur Kabupaten Tabanan (Perspektif Teologi Hindu). Skripsi. Bali: Institut Hindu Dharma Negeri Denpasar.

Satria, C., Pemayun, T.U.N., \& Suteja, I.K. (2017). Fotografi Decopauge Keindahan dan Fenomena Subak Bali di Daerah Gianyar dan Bangli. Jurnal Prabangkara, 21(2), 51-57.

Setiyanto, M.A.C. (2012). Peranan Awigawig Subak dalam Pengelolaan Lingkungan Hidup (Sudut Pandang 
Hukum Lingkungan). Jurnal $A r$ Risalah, 10(26), 29-36.

Sumiyati, Sutiarso, L., Windia, W., \& Sudira, P. (2011). Evaluasi Kinerja Fisik Sistem Subak Yang Berorientasi Agroekowisata Menggunakan Pendekatan Logika Fuzzy. Jurnal Teknik Industri, 12(2), 147-155.

Sunaryasa, I.M.O. (2002). Upaya Revitalisasi Peran Subak dalam Pelestarian Fungsi Lingkungan (Studi Kasus: Subak Jati Luwih dan Subak Kloda, Tabanan-Bali). Tesis, Semarang: Program Pasca Sarjana, Universitas Diponegoro.

Suradisastra, K \& A. Dariah. (2002). Pemetaan Kearifan Lokal dan Kapital Sosial pada Kegiatan Pertanian Lahan Kering.

Sutawan, N. (2001). Eksistensi Subak di Bali: Mampukah bertahan Menghadapi Berbagai Tantangan. Denpasar: Jurusan Sosial Ekonomi Pertanian Fakultas Pertanian Udayana.

Suyastiri, N.M. (2012). Pemberdayaan Subak melalui "Green Tourism" Mendukung
Keberlanjutan Pembangunan Pertanian di Bali. Jurnal SEPA, 8(2), 168-173.

Tarigan, H., Dharmawan, A.H., Tjondronegoro, S.M.P., \& Suradisastra, K. (2013). Pertarungan Akses Sumberdaya Air Keterancaman Subak Pada Lahan Persawahan di Kabupaten Tabanan, Bali. Bogor: Institut Pertanian Bogor.

Windia, W., Pusposutardjo, S., Sutawan, N., Sudira, P., \& Arif, S.S. (2011). Transformasi Sistem Irigasi Subak yang Berlandaskan Konsep Tri Hita Karana (THK). Universitas Udayana, Denpasar dan Universitas Gadjah Mada, Yogyakarta, 1-15.

Windia, W. (2012). Sistem Irigasi Subak dengan Landasan Tri Hita Karana (THK) sebagai Teknologi Sepadan dalam Pertanian Beririgasi. Universitas Udayana, Denpasar dan Universitas Gadjah Mada, Yogyakarta, 1-13. 